\title{
Male territorial aggression and androgen modulation in high latitude populations of the Sooty, Passerella iliaca sinuosa, and Red Fox Sparrow, Passerella iliaca zaboria
}

\author{
Douglas W. Wacker · Alexander J. Coverdill • \\ Carolyn M. Bauer $\cdot$ John C. Wingfield
}

Received: 22 October 2008/Revised: 11 March 2009/Accepted: 25 May 2009/Published online: 26 June 2009

(C) The Author(s) 2009. This article is published with open access at Springerlink.com

\begin{abstract}
The Fox Sparrows, Passerella iliaca, include multiple groups and subspecies distributed at several latitudes from the Alaskan arctic to the southwestern United States. As such, this species represents a potential model for investigating latitudinal variation in androgen secretion and aggressive territoriality in male passerines. Breeding male Fox Sparrows from two subspecies within two groups, the Sooty Fox Sparrow, P. i. sinuosa, and the Red Fox Sparrow, $P$. i. zaboria, were assessed for aggressive territoriality and androgen responsiveness at multiple latitudes in arctic and subarctic Alaska. Subarctic Sooty Fox Sparrows had higher circulating androgen levels in the early $(8.54 \mathrm{ng} / \mathrm{ml})$ versus mid-late breeding season $(2.44 \mathrm{ng} / \mathrm{ml})$. Males in the midlate breeding season did not up-regulate androgen secretion in response to social challenge, but were aggressive and spent more time within $5 \mathrm{~m}$ of a decoy during a simulated territorial intrusion (STI) than early breeding males. Male
\end{abstract}

Communicated by C. G. Guglielmo.

\section{W. Wacker}

Graduate Program in Neurobiology and Behavior,

University of Washington, Box 351800, Seattle,

WA 98195, USA

D. W. Wacker $(\bowtie)$

Centre for Integrative Physiology,

University of Edinburgh, Edinburgh EH8 9XD, UK

e-mail:dwacker@staffmail.ed.ac.uk

A. J. Coverdill - C. M. Bauer

Department of Biology, University of Washington,

Box 351800, Seattle, WA 98195, USA

J. C. Wingfield

College of Biological Sciences,

University of California Davis, BRIGGS 294,

Davis, CA 95616, USA subarctic Red Fox Sparrows had slightly higher circulating androgen levels $(2.29 \mathrm{ng} / \mathrm{ml})$ than arctic males $(1.10 \mathrm{ng} / \mathrm{ml})$ in the mid-late breeding season. However, androgen levels were not correlated with blood collection time after a social challenge in either group, suggesting that neither arctic nor subarctic males up-regulate androgen secretion during the mid-late breeding period. Arctic males spent more time within $5 \mathrm{~m}$ of a decoy and sang less than subarctic males during an STI in the mid-late breeding season. These findings demonstrate that the Fox Sparrow is a tractable model for investigating the latitudinal regulation of aggressive territoriality and androgen responsiveness in passerines.

Keywords Passerella $\cdot$ Testosterone - Aggression · Latitude $\cdot$ Androgen

\section{Introduction}

Numerous studies have described aggressive territoriality and the regulation of androgen secretion in breeding male passerines (Harding and Follett 1979; Hunt et al. 1995; Meddle et al. 2002; Wingfield 1984, 1985; Wingfield and Hahn 1994). Many have utilized models from the family Emberizidae, most notably the White-crowned Sparrow, Zonotrichia leucophrys, and Song Sparrow, Melospiza melodia. Aggression in Emberizids is usually high in the early breeding season during territory initiation and is associated with elevated circulating androgen levels. These levels typically decrease in the midlate breeding season, but are still elevated when compared with levels in non-breeding life history stages (Hunt et al. 1999; Wingfield and Farner 1978; Wingfield and Hahn 1994).

Males in pairs that normally produce multiple broods within a single breeding season, such as the Puget Sound subspecies of the White-crowned Sparrow, Zonotrichia 
leucophrys pugetensis, often respond to conspecific territorial challenges in the mid-late breeding season by transiently increasing plasma androgens (Wingfield et al. 1990, 2007; Wingfield and Hahn 1994). This is hypothesized to allow these males to reap the benefits of having high androgen levels during a territorial dispute without suffering the energetic costs associated with maintaining these levels continually (Wingfield et al. 1990, 2001). Males in species or populations that typically do not raise multiple broods, such as the high arctic breeding Gambel's White-crowned Sparrow, Zonotrichia leucophrys gambelii, and Lapland Longspur, Calcarius lapponicus, do not transiently up-regulate circulating androgens during territorial disputes (Goymann et al. 2007; Hunt et al. 1995; Meddle et al. 2002).

The breeding season for high latitude breeding birds is both short and synchronous, as dictated by the brevity of the arctic summer (Hunt et al. 1995; Wingfield and Hunt 2002). Owing to this synchronicity, many arctic breeding birds are obligatorily singly brooded, and it is therefore uncommon for one male to be in an early territory initiation phase while another neighboring male is in a later breeding substage in these regions, especially in monogamous species where males provide some paternal care (Hunt et al. 1995; Wingfield et al. 1990). Interestingly, peak testosterone levels are positively correlated with absolute latitude (Garamszegi et al. 2008). These levels reflect early breeding when sexual behavior is displayed and territories are initiated (Garamszegi et al. 2008; Hunt et al. 1995; Wingfield et al. 1990). Birds that migrate long distances to breed over a short season are hypothesized to encounter high levels of conspecific competition for mates and territories upon arrival on their breeding grounds, thus they have higher androgen levels to deal with these conditions (Garamszegi et al. 2008; Wingfield et al. 1990). However, high circulating androgen levels in mid-late breeding stages would be problematic for species that provide paternal care, as experimental increases in testosterone have been shown to negatively affect chick feeding rates and development (Hegner and Wingfield 1987; Hunt et al. 1999; Ketterson et al. 1992; Lynn et al. 2005). Therefore, the ability to socially up-regulate androgen secretion later in the breeding season, to properly respond to territorial disputes and/or prepare for mating to produce subsequent broods, uncommon at these latitudes, may have been lost. Male passerines that only show aggression for brief periods at the beginning of their breeding season and provide high levels of parental care are more likely to have higher peak seasonal androgen levels ( $R_{\text {seasonal }}$ in Goymann et al. 2007) than males who are continuously aggressive throughout the breeding season and provide little or no parental care. However, the transient up-regulation of androgens $\left(\mathrm{R}_{\text {male-male }}\right.$ in Goymann et al. 2007) does not correlate with the ratio of male aggression to paternal care (Goymann et al. 2007). Therefore, high latitude breeding males that provide paternal care in pairs that produce single broods should have high androgen levels in the early breeding season as compared to the mid-late breeding season and should not up-regulate androgen secretion in response to social challenge in later breeding substages.

Subspecies comparisons within Zonotrichia leucophrys have presented an excellent model for investigating the latitudinal regulation of androgen secretion, its social modulation, and how it affects aggressive breeding territoriality. However, in order to generalize these findings, it is necessary to establish an additional model passerine, and especially Emberizid species and subspecies, to investigate these phenomena and tease apart the possible effects of phylogeny (Hirschenhauser et al. 2003). The Fox Sparrow, Passerella iliaca, has potential in this regard. While there is currently only one recognized species of Fox Sparrow, Passerella iliaca (A.O.U. 1998), there has been ongoing scholarly discussion regarding separation of this taxon into four separate species, the Red Fox Sparrow (Passerella iliaca), Sooty Fox Sparrow (Passerella unalaschcensis), Slate-colored Fox Sparrow (Passerella schistacea), and Thick-billed Fox Sparrow (Passerella megarhyncha) (Burns 1993; Weckstein et al. 2002; Zink 1994; Zink and McKitrick 1995; Zink and Weckstein 2003). Currently, these potential species are referred to simply as "groups". Within these four groups are 14-18 subspecies whose distributions span areas of the western United States and much of Canada (A.O.U. 1957; Cramps and Perrins 1994; Weckstein et al. 2002). Within these subspecies, there are long- and short-distant migrants (Austin 1968; Bell 1997; Mailliard 1921), altitudinal migrants (Swarth 1920), resident populations (Cramps and Perrins 1994), and hybridization between groups (Webster 1975; Zink 1994), making Passerella iliaca ripe for subspecies and latitudinal comparisons of aggression and related androgen secretion. Previously, aggressive territoriality in Fox Sparrows has received very little scholarly attention (Weckstein et al. 2002), but has been observed in free-living males (Blacquiere 1979; Martin 1980). Related androgen modulation has yet to be investigated. This paper outlines patterns of male breeding aggression and androgen secretion at multiple latitudes in the Fox Sparrow. We have examined two subspecies within two groups of migratory Fox Sparrow, the Red Fox Sparrow, P. i. zaboria, and the Sooty Fox Sparrow, P. i. sinuosa.

\section{Methods}

Study species and area

All procedures were performed in accordance with University of Washington Animal Care and Use Committee 
guidelines. Male Sooty Fox Sparrows, $P$. i. sinuosa were tested for aggressive territoriality and captured from multiple sites at roughly the same latitude $\left(\sim 60^{\circ} \mathrm{N}\right)$ in south central Alaska, from approximately $30 \mathrm{~km}$ south of Anchorage, down into the Kenai Peninsula in May and June of 2005, representing the early and mid-late breeding season respectively (Looff 1939). Mid-late breeding Sparrows were seen paired with females and/or carrying insects, likely food for their young. Sites were generally swampy with brush and overhanging trees, and represent the northernmost extent of the breeding range for this subspecies (Austin 1968; Bell 1997; Swarth 1920). Male Red Fox Sparrows, P. i. zaboria, were tested for aggressive territoriality and captured from multiple sites in arctic $\left(\sim 67-69^{\circ} \mathrm{N}\right.$, along the Dalton Highway) and subarctic ( $\sim 64-65^{\circ} \mathrm{N}$, around and north of Fairbanks), Alaska, in June 2006 and 2007, representing the mid-late breeding season (A.B.O. 2005). Arctic sites typically consisted of low brush and/or willow often near a stream or other water source. Fox Sparrows captured in these areas were at the northernmost extent of their normal breeding range. The farthest north bird identified in this study was located at $69^{\circ} 09.078^{\prime} \mathrm{N}$, Happy Valley, Alaska, consistent with findings from North American Breeding Bird Surveys (U.S.G.S. 1993-2007). Subarctic sites were generally more variable than arctic sites, including recently burned spruce forests, brush and overhanging trees, and swampy areas.

Field tests and blood collection

Aggressive territoriality was assessed with a simulated territory intrusion (STI), as described in Wingfield and Hahn (1994). Briefly, birds were located visually or aurally with limited conspecific song playback. A caged male conspecific decoy was then placed within the territory of the focal male. The STI was initiated by removing the cover on this cage and playing a series of pre-recorded conspecific songs from a portable speaker for $10 \mathrm{~min}$. During this period, five measures of aggression were recorded: the number of songs in response to the STI, the number of flights towards the decoy bird, the closest approach to the decoy bird (m), the time spent within $5 \mathrm{~m}$ from the decoy bird (s), and the latency to any of these aggressive acts (s). Territorial aggression involving song, flights, and chases has been previously observed between free-living male Fox Sparrows (Blacquiere 1979; Martin 1980). Birds that did not respond or that left the area at the initiation of an STI were excluded from the study. At the termination of each 10 min STI, mistnets were erected and attempts were made to catch the focal bird. Capture was facilitated by additional exposure to song playback and the decoy. Blood was taken from each captured bird from the alar (wing) vein and kept on ice in the field. Blood was subsequently centrifuged and plasma was drawn off and frozen for androgen radioimmunoassay. Birds captured to assess unstimulated levels of circulating androgens were lured into mistnets utilizing a decoy and conspecific song playback or conspecific song playback alone. These birds were bled in less than $10 \mathrm{~min}$ from the initiation of playback, as it has previously been demonstrated that it takes at least $10 \mathrm{~min}$ for circulating androgen levels to rise significantly after the initiation of an STI in breeding, male Emberizid sparrows (Wingfield and Wada 1989). Therefore, with regard to detecting challenge induced differences in androgen secretion, all stimulated birds were captured after 10 min using both a decoy and conspecific song playback; all birds captured before $10 \mathrm{~min}$ were considered unstimulated.

\section{Radioimmunoassay}

Plasma androgen levels were measured in duplicate by direct radioimmunoassay after extraction with dichloromethane as described in (Wingfield and Farner 1975) in three separate assays. The androgen antibody used (Wien Laboratories, Succasunna, NJ) binds equally well to both testosterone (T) and dihydrotestosterone (DHT). The average lower detection limit was $0.05 \mathrm{ng} / \mathrm{ml}$. The average intra-assay variation for the assays was $10 \%$. Interassay variation was $13 \%$.

Statistical analyses

Means \pm standard errors are presented. In order to identify particular behaviors that differ between early and mid-late breeding Sooty Fox Sparrows, as well as between arctic and subarctic breeding Red Fox Sparrows, behaviors compromising the simulated territorial intrusion were analyzed separately as described in Wingfield and Hahn (1994). Normally distributed datasets with equal variance were analyzed with $t$ tests to detect significant differences between groups. If datasets were non-normal, natural log transformations were attempted to achieve normality. Otherwise, nonparametric Mann-Whitney tests were utilized to compare groups. Baseline plasma androgen levels for stimulated and unstimulated Sooty Fox Sparrow males in the mid-late breeding season were compared with a $t$ test. The subsequent test of early versus mid-late breeding levels included only unstimulated birds. As unstimulated birds from the stimulation test were included in the breeding stage comparison, both of these tests were evaluated at a Bonferroni adjusted alpha of 0.025. Plasma androgen levels for arctic and subarctic Red Fox Sparrows were regressed against time to blood collection; $r^{2}$ and $P$ values are reported. Statistical analyses were conducted 
on either JMP 7.0 (SAS Institute, Cary, NC) or SigmaStat 3.1 (Systat Software, San Jose, CA).

\section{Results}

In the mid-late breeding season, a 10-min STI did not lead to significant increases in circulating androgen levels over levels in non-stimulated male Sooty Fox Sparrows $\left(t_{0.025(2), 18}=-0.798, P=0.435\right.$; Fig. 1a), suggesting that this group does not transiently increase androgen levels in response to challenge at this breeding latitude. Male Sooty Fox Sparrows had significantly higher circulating androgen levels in the early $(8.54 \pm 3.62 \mathrm{ng} / \mathrm{ml})$ versus $\mathrm{mid}-$ late $(2.44 \pm 0.81 \mathrm{ng} / \mathrm{ml})$ breeding season [ $\ln ($ androgen levels) $t_{0.025(1), 14}=-2.306, P<0.025$; Fig. 1b]. However, levels in the mid-late breeding season were still well above the level of detection for the assay. Circulating androgen levels
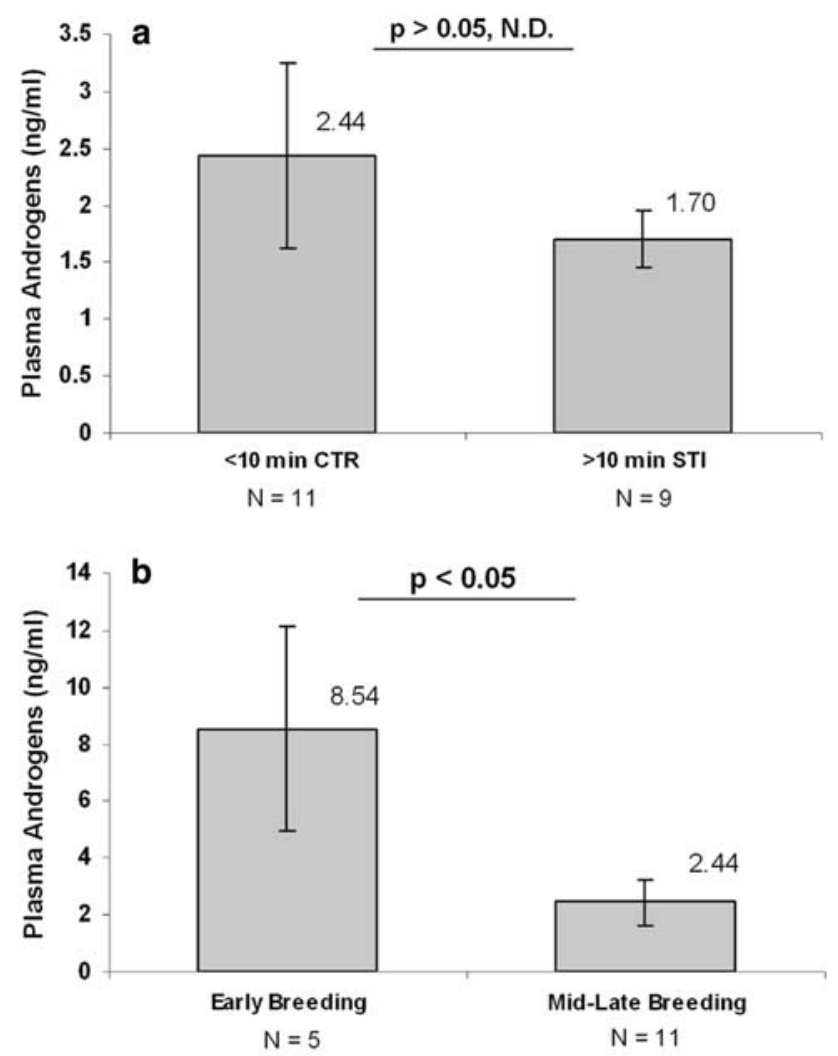

Fig. 1 a Breeding male Sooty Fox Sparrows, Passerella iliaca sinuosa, did not up-regulate androgen secretion (T and DHT) in response to challenge in the mid-late breeding season. $<10 \mathrm{~min} C T R$, control birds captured and bled in less than $10 \mathrm{~min}$ from the initiation of conspecific song playback; $>10$ min STI, birds captured and bled after a $10 \mathrm{~min}$ simulated territorial intrusion; $N D$ not significantly different. b Male Sooty Fox Sparrows in the early breeding season had significantly higher circulating androgen levels than those in the mid-late breeding season; only unstimulated birds were included in this analysis in the non-breeding life history stages are usually undetectable in Emberizid sparrows, suggesting that these midlate breeding levels were still elevated.

Male Sooty Fox Sparrows were aggressive in both the early and mid-late breeding season. The response latency $\left(t_{0.05(2), 15}=-0.923, \quad P=0.371\right)$, number of songs $\left(t_{0.05(2), 15}=-0.137, P=0.893\right)$, flights $\left(t_{0.05(2), 15}=\right.$ $-0.911, P=0.377)$, and closest approach $\left(U_{0.05(2), 8,9}=\right.$ 81.500, $P=0.386$ ) were not significantly different between early and mid-late breeding substages (Table 1). However, the time within $5 \mathrm{~m}$ of the decoy was significantly higher in the mid-late versus early breeding season $\left(t_{0.05(2), 15}=-3.601, P<0.005\right.$; Table 1$)$.

Circulating androgen levels were significantly higher in subarctic $(2.29 \pm 0.39 \mathrm{ng} / \mathrm{ml})$ versus arctic $(1.10 \pm$ $0.32 \mathrm{ng} / \mathrm{ml})$ Red Fox Sparrow males $\left(t_{0.05(2), 18}=2.202\right.$, $P<0.05)$. However, these levels did not correlate with the time from the initiation of conspecific song playback to successful blood collection in either arctic $\left(r^{2}=0.003\right.$, $P=0.8705)$ or subarctic $\left(r^{2}=0.080, P=0.4367\right)$ birds, suggesting that male Red Fox Sparrows do not up-regulate androgen release in response to an STI at these latitudes. As more birds were captured before $10 \mathrm{~min}$ in the subarctic and after $10 \mathrm{~min}$ in the arctic, the two datasets were combined and reassessed. Androgen levels in the combined grouping did not correlate with time to blood collection ( $r^{2}=0.063, P=0.3019$; Fig. 2).

Both subarctic and arctic male Red Fox Sparrows showed aggression in response to an STI. The number of flights $\left(U_{0.05(2), 8,10}=87.500, \quad P=0.328\right)$ and closest approach $\left(U_{0.05(2), 8,10}=85.500, P=0.424\right)$ were not significantly different between these groups (Table 1). There was a non-significant trend for arctic birds to respond to an STI more quickly with an aggressive act than subarctic birds $\left(U_{0.05(2), 8,10}=96.500, P=0.076\right)$. Birds in the arctic spent significantly more time within $5 \mathrm{~m}$ of the decoy than birds in the subarctic $\left(U_{0.05(2), 8,10}=53.000\right.$, $P<0.05)$, while subarctic birds sang significantly more than arctic birds in response to the STI $\left(t_{0.05(2), 16}=2.490\right.$, $P<0.05$ ) (Table 1). Subarctic birds often initially responded robustly to the STI, only to fly off to a nearby tree to sing or leave the area all together as time wore on. Arctic birds generally remained interested in the playback and decoy long after the STI and, unlike the subarctic birds, were often caught long after the termination of the STI.

\section{Discussion}

As predicted, circulating androgen levels were greater in the early versus mid-late breeding season in male Sooty Fox Sparrows. This further supports the hypothesis that male passerines avoid the costs of maintaining high levels 
Table 1 Aggression in early versus mid-late breeding male Sooty Fox Sparrows, Passerella iliaca sinuosa, and subarctic versus arctic breeding male Red Fox Sparrows, $P$. i. zaboria (mean \pm SEM)

\begin{tabular}{|c|c|c|c|c|c|}
\hline & Response latency (s) & Songs & Flights & Closest approach (m) & Time within $5 \mathrm{~m}$ of decoy (s) \\
\hline \multicolumn{6}{|l|}{ Sooty Fox Sparrow } \\
\hline Early breeding & $13 \pm 4$ & $53 \pm 7$ & $13 \pm 4$ & $1.0 \pm 0.4$ & $259 \pm 72 *$ \\
\hline Mid-late breeding & $21 \pm 6$ & $54 \pm 7$ & $18 \pm 4$ & $0.5 \pm 0.2$ & $521 \pm 25^{*}$ \\
\hline \multicolumn{6}{|l|}{ Red Fox Sparrow } \\
\hline Subarctic & $45 \pm 22$ & $40 \pm 5^{*}$ & $7 \pm 3$ & $2.2 \pm 0.5$ & $232 \pm 55^{*}$ \\
\hline Arctic & $14 \pm 2$ & $23 \pm 5^{*}$ & $5 \pm 2$ & $2.4 \pm 1.1$ & $429 \pm 74^{*}$ \\
\hline
\end{tabular}

* Significant difference

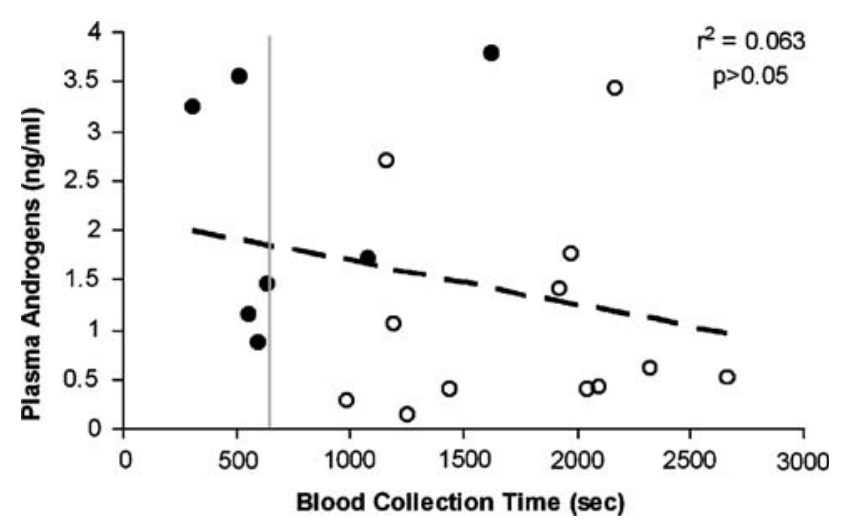

Fig. 2 Circulating androgen levels ( $\mathrm{T}$ and DHT) do not correlate with the time from conspecific song playback to blood collection in breeding male Red Fox Sparrows captured in arctic and subarctic Alaska. The vertical grey line is the 10-min mark; points before this line represent unstimulated birds, points after this line represent stimulated birds. Subarctic birds (black circles), arctic birds (open circles)

of circulating androgens by lowering levels after territory initiation and mating has occurred (Wingfield and Farner 1978; Wingfield and Hahn 1994). The Sooty Fox Sparrows in this study are long-distance migrants (Bell 1997; Swarth 1920), so increased androgen secretion may help the males compete for mates and territories upon their arrival on the breeding grounds (Garamszegi et al. 2008; Wingfield et al. 1990).

Subarctic and arctic Red Fox Sparrows were captured in the mid-late breeding season only. Androgen levels were significantly different between these groups, but levels in both groups were typical of those seen in Emberizids in the mid-late breeding season (Hunt et al. 1995; Wingfield and Hahn 1994). However, in view of the different circulating androgen levels, it is possible that the two groups of birds were in slightly different breeding substages. Yet, Fox Sparrows breeding at more temperate latitudes establish territories within 1 day after arrival, and establish pair bonds within a week (Threlfall and Blacquiere 1982). There is no reason to predict that more synchronous breeding populations would take longer to finish these substages. Considering the probable May arrival of these birds (A.B.O. 2005) and the brevity of the breeding season, it is likely that birds from both groups were no longer initiating territories, but were rather in a later breeding substage. More behavioral data, as well as the entire breeding profile of unstimulated circulating androgen levels for both arctic and subarctic males, should be collected in the future to firmly establish any potential latitudinal differences in breeding substage cycles.

Neither male Red nor Sooty Fox Sparrows up-regulated androgen secretion in response to social challenge (STI) in the mid-late breeding season. It is possible that the brevity of this life history stage has created sufficient breeding synchrony in both of these Fox Sparrow groups to make preparedness for conspecific altercation in the mid-late breeding season less necessary, since most males will attempt to usurp territories only earlier in the season. Based on our surveys, the northernmost reach of the Sooty Fox Sparrow breeding range is $1,300+\mathrm{km}$ farther south than the northernmost reach of the Red Fox Sparrow breeding range. If one considers Fox Sparrows as a single species, then according to the "short season" hypothesis, Sooty Fox Sparrows would be predicted to socially up-regulate testosterone in the mid-late breeding season, as their breeding season is longer and potentially less synchronous than that of Red Fox Sparrows breeding at much higher latitudes (Garamszegi et al. 2008; Hunt et al. 1999; Lynn 2008). There is, of course, an ongoing debate as to whether Sooty and Red Fox Sparrows should represent two different species. It may be that what is a "short breeding season" for Sooty Fox Sparrows is very different from that for Red Fox Sparrows.

The lack of social up-regulation of androgen secretion after an STI likely represents a trade-off between territory maintenance and paternal investment (Hunt et al. 1999; Reed et al. 2006). Experimentally elevated testosterone during the mid-late breeding season has been shown to decrease paternal feeding rates, and ultimately delay chick development and lower chick survival in multiple bird species (Hegner and Wingfield 1987; Hunt et al. 1999; Ketterson et al. 1992; Lynn et al. 2005). Paternal feeding 
has been documented in Fox Sparrows (Philipp 1925), but has not been thoroughly investigated in these populations. Males were seen carrying insects in the mid-late breeding period, which suggests that they may either provision young or the female. The essential paternal care hypothesis (Lynn et al. 2005) states that if males are critical to reproductive success, insensitivity to androgens might arise. Although androgen sensitivity was not addressed in this study, Goymann et al. (2007) predicts that a lack of social up-regulation of androgens in response to conspecific challenge would also occur under such conditions. Future studies should address the necessity of paternal care in these and other Fox Sparrow groups.

Whether males within a group of birds up-regulate androgen secretion in response to challenge may also be associated with the capability of pairs within that group to produce multiple broods (Goymann et al. 2007). The potential for double brooding in Fox Sparrows has not been thoroughly investigated (Weckstein et al. 2002); however, there is one published report of Fox Sparrows raising multiple broods near Juneau, Alaska (Rogers 1994). The persistence of aggression into the mid-late breeding season in the Fox Sparrows in this study points to the possibility of multiple brooding. However, the lack of androgen secretion in response to challenge in all examined groups makes this possibility less likely (Goymann et al. 2007). Birds may have lost the ability to socially up-regulate androgen secretion in the mid-late breeding season as the costs to parental investment would outweigh any benefits for territory defence and/or sexual behavior at this time. The extreme brevity of the breeding season in arctic Red Fox Sparrows also likely precludes double-brooding. However, more data should be collected to address whether multiple brooding is common in multiple subspecies of Fox Sparrow at multiple latitudes.

Despite a lack of challenge-induced up-regulation, midlate breeding androgen levels remain well above what would be expected in a non-breeding life history stage. Higher androgen levels in the early breeding season in Sooty Fox Sparrows may be involved in the maintenance of sexual behavior (Goymann et al. 2007; Lynn and Wingfield 2008). The mid-late breeding levels for both Sooty and Red Fox Sparrows reported here may be high enough to facilitate the aggression seen in response to an STI during these later substages. It is also possible that mid-late breeding aggression is relatively independent of circulating androgens (Lynn 2008; Meddle et al. 2002) and may be regulated by neural changes in steroid signaling or production (Soma et al. 1999a, b, 2003). Uncoupling circulating steroid levels and steroid-based behavior via such a mechanism might also help to avoid the aforementioned costs of high circulating androgen levels (Hau 2007; Wingfield et al. 2001).

The expression of aggression between the two breeding periods in Sooty Fox Sparrows was not identical. In the mid-late breeding season, males spent significantly more time within $5 \mathrm{~m}$ of the decoy than those in the early breeding season. The context in which aggressive behaviors are expressed is very important in understanding their physiological and endocrine regulation (Garamszegi et al. 2008; Wacker et al. 2008; Wingfield et al. 2006). It is possible that an early reluctance to approach the decoy is correlated with mate guarding in the early stages of breeding territoriality. Future studies should determine the function of the differential expression of early and mid-late breeding aggression in this group of Fox Sparrows.

In the Red Fox Sparrows examined, subarctic males sang more, but remained farther from the decoy during the STIs than arctic males. These differences in aggression might be due to differences in the general habitat for both sets of populations. Arctic areas had less tree cover and mostly consisted of low-growing willow and alder. While subarctic birds often flew up to the top of nearby trees to sing, arctic birds could not do so. Arctic birds were often observed on the ground, within the brush near the decoy. Many scratched at the ground, perhaps in a display of displaced aggression, a behavior that has been previously noted in territorial disputes between Fox Sparrows (Blacquiere 1979). The increased ground cover and lack of high perching areas may have contributed to the observed differences in aggressive behavior. If, as previously discussed, arctic and subarctic males were in different breeding substages, then this also might help to explain differences seen in their behavior.

Throughout this work, we have described the aggressive territoriality and androgen responsiveness of two subspecies within two groups of Fox Sparrow, across multiple latitudes. Future studies should address early breeding season aggression and androgen responsiveness in arctic and subarctic Red Fox Sparrows and other groups and subspecies within this clade at more temperate latitudes. Due to its subspecific and group diversity in distribution, migration, and behavior, this species as a whole represents a valuable model towards investigating the latitudinal variation in androgen secretion and aggressive territoriality in male passerines.

\section{Zusammenfassung}

Territoriale Aggression von Männchen und Androgenmodulation in Populationen der Fuchsammer nördlicher Breite: Passerella iliaca sinuosa und Passerella iliaca zaboria

Die Fuchsammern, Passerella iliaca, umfassen mehrere Gruppen und Unterarten, die in unterschiedlichen geographischen Breiten von der Arktis Alaskas bis in den Südwesten der USA vorkommen. Daher stellt diese Art ein 
mögliches Modell dar, um Schwankungen in Androgensekretion und aggressiver Territorialität männlicher Sperlingsvögel mit dem Breitengrad zu untersuchen. Brütende männliche Fuchsammern zweier Unterarten aus zwei Gruppen $P$. i. sinuosa und $P$. i. zaboria wurden bezüglich ihrer aggressiven Territorialität und Androgenresponsivität in unterschiedlichen Breiten in der arktischen und subarktischen Zone Alaskas untersucht. Subarktische Passerella iliaca sinuosa hatten höhere zirkulierende Androgenlevel in der frühen $(8.54 \mathrm{ng} / \mathrm{ml})$ verglichen mit der mittleren bis späten Brutsaison (2.44 ng/ml). Männchen in der mittleren bis späten Brutsaison regulierten die Androgensekretion nicht hoch als Antwort auf soziale Herausforderungen, waren jedoch aggressiv und verbrachten mehr Zeit als früher brütende Männchen im Umkreis von fünf Metern um einen Lockvogel während eines simulierten Eindringens ins Territorium (STI). Männliche subarktische Passerella iliaca zaboria hatten geringfügig höhere zirkulierende Androgenlevel $(2.29 \mathrm{ng} / \mathrm{ml})$ als arktische Männchen $(1.10 \mathrm{ng} / \mathrm{ml})$ in der mittleren bis späten Brutsaison. Die Androgenlevel korrelierten jedoch in keiner der Gruppen mit der Blutentnahmezeit nach einer sozialen Herausforderung, was darauf hindeutet, dass weder arktische noch subarktische Männchen die Androgensekretion während der mittleren bis späten Brutperiode hochregulieren. Arktische Männchen verbrachten mehr Zeit im Umkreis von fünf Metern um einen Lockvogel und sangen weniger als subarktische Männchen während einer STI in der mittleren bis späten Brutsaison, Diese Befunde zeigen, dass die Fuchsammer ein geeignetes Modell ist, um die Regulation der aggressiven Territorialität und Androgenresponsivität in Abhängigkeit vom Breitengrad bei Sperlingsvögeln zu untersuchen.

Acknowledgments Part of the work presented here was funded by a Grant In Aid of Research by the Arctic Institute of North America and the Richard C Snyder Award for Graduate Student Research in Vertebrate Zoology at the University of Washington. J.C.W. acknowledges from the National Science Foundation, Office of Polar Programs, grant number OPP-9911333. Special thanks are given to Brian Walker and Sara O'Brien for help in the field, and Alexander (Sasha) Kitaysky for providing field equipment at a time of great need. The Alaska Bird Observatory provided valuable information about the arrival and departure of Fox Sparrows around Fairbanks, AK (http://www.alaskabird.org). All experiments described herein comply with all federal (United States), state, and local laws.

Open Access This article is distributed under the terms of the Creative Commons Attribution Noncommercial License which permits any noncommercial use, distribution, and reproduction in any medium, provided the original author(s) and source are credited.

\section{References}

A.B.O. Alaska Bird Observatory (2005) Banding records 1992-2005. Alaska Bird Observatory, Fairbanks
A.O.U. American Ornithologists' Union (1957) Check-list of North American birds. American Ornithologists' Union, Baltimore

A.O.U. American Ornithologists' Union (1998) Check-list of North American birds. American Ornithologists' Union, Washington, DC Austin OL Jr (1968) Fox Sparrow [various subspecies]. In: Austin OL $\mathrm{Jr}$ (ed) Life histories of North American cardinals, grosbeaks, buntings, towhees, finches, sparrows and their allies. US Natl Mus Bull 237(3):1392-1395, 1415-1434

Bell CP (1997) Leap-frog migration in the fox sparrow: minimizing the cost of spring migration. Condor 99:470-477

Blacquiere JR (1979) Some aspects of the breeding biology and vocalizations of the fox sparrow (Passerella iliaca Merrem) in Newfoundland. M.Sc. Memorial University, St John's, NF

Burns KJ (1993) Geographic variation in ontogeny of the fox sparrow. Condor 95:652-661

Cramp S, Perrins M (1994) Fox sparrow. In: Cramp S, Perrins M (eds) The birds of the Western Palearctic, vol 8. Oxford University Press, Oxford, pp 84-86

Garamszegi LZ, Hirschenhauser K, Bokony V, Eens M, HurtrezBousses S, Moller AP, Oliveira RF, Wingfield JC (2008) Latitudinal distribution, migration, and testosterone levels in birds. Am Nat 172:533-546

Goymann W, Landys MM, Wingfield JC (2007) Distinguishing seasonal androgen responses from male-male androgen responsiveness-revisiting the challenge hypothesis. Horm Behav 51:463-476

Harding CF, Follett BK (1979) Hormone changes triggered by aggression in a natural population of blackbirds. Science 203:918-920

Hau M (2007) Regulation of male traits by testosterone: implications for the evolution of vertebrate life histories. Bioessays 29:133-144

Hegner RE, Wingfield JC (1987) Effects of experimental manipulation of testosterone levels on parental investment and breeding success in male house sparrows. Auk 104:462-469

Hirschenhauser K, Winkler H, Oliveira RF (2003) Comparative analysis of male androgen responsiveness to social environment in birds: the effects of mating system and paternal incubation. Horm Behav 43:508-519

Hunt K, Wingfield JC, Astheimer LB, Buttemer WA, Hahn TP (1995) Temporal patterns of territorial behaviour and circulating testosterone in the Lapland longspur and other arctic passerines. Am Zool 35:274-284

Hunt KE, Hahn TP, Wingfield JC (1999) Endocrine influences on parental care during a short breeding season: testosterone and male parental care in Lapland longspurs (Calcarius lapponicus). Behav Ecol Sociobiol 45:360-369

Ketterson ED, Nolan V Jr, Wolf L, Ziegenfus C (1992) Testosterone and avian life histories: effects of experimentally elevated testosterone on behaviour and correlates of fitness in the darkeyed junco (Junco hyemalis). Am Nat 140:980-999

Looff HB (1939) Returns of golden-crowned and kadiak fox sparrows to breeding grounds on Kodiak Island, Alaska. Bird-Banding $10: 85-88$

Lynn SE (2008) Behavioural insensitivity to testosterone: why and how does testosterone alter paternal and aggressive behaviour in some avian species but not others? Gen Comp Endocrinol 157:233-240

Lynn SE, Wingfield JC (2008) Dissociation of testosterone and aggressive behaviour during the breeding season in male chestnut-collared longspurs, Calcarius ornatus. Gen Comp Endocrinol 156:181-189

Lynn SE, Walker BG, Wingfield JC (2005) A phylogenetically controlled test of hypotheses for behavioural insensitivity to testosterone in birds. Horm Behav 47:170-177

Mailliard JW (1921) Notes on fall migrations of fox sparrows in California. Condor 23:178-182 
Martin DJ (1980) Response by male fox sparrows to broadcast of particular conspecific songs. Wilson Bull 92:21-32

Meddle SL, Romero LM, Astheimer LB, Buttemer WA, Moore IT, Wingfield JC (2002) Steroid hormone interrelationships with territorial aggression in an Arctic-breeding songbird, Gambel's white-crowned sparrow, Zonotrichia leucophrys gambelii. Horm Behav 42:212-221

Philipp PB (1925) Notes on some summer birds of the Magdalen islands. Can Field Nat 39:75-78

Reed WL, Clark ME, Parker PG, Raouf SA, Arguedas N, Monk DS, Snajdr E, Nolan V Jr, Ketterson ED (2006) Physiological effects on demography: a long-term experimental study of testosterone's effects on fitness. Am Nat 167:667-683

Rogers CM (1994) Avian nest success, brood parasitism and edgeindependent reproduction in an Alaskan wetland. J Field Ornithol 64:433-586

Soma KK, Bindra RK, Gee J, Wingfield JC, Schlinger BA (1999a) Androgen-metabolizing enzymes show region-specific changes across the breeding season in the brain of a wild songbird. J Neurobiol 41:176-188

Soma KK, Hartman VN, Wingfield JC, Brenowitz EA (1999b) Seasonal changes in androgen receptor immunoreactivity in the song nucleus HVc of a wild bird. J Comp Neurol 409:224-236

Soma KK, Schlinger BA, Wingfield JC, Saldanha CJ (2003) Brain aromatase, 5 alpha-reductase, and 5 beta-reductase change seasonally in wild male song sparrows: relationship to aggressive and sexual behaviour. J Neurobiol 56:209-221

Swarth HW (1920) Revision of the avian genus Passerella with special reference to the distribution and migration of the races in California. Univ Calif Publ Zool 21:75-224

Threlfall W, Blacquiere JR (1982) Breeding biology of the fox sparrow Passerella iliaca in Newfoundland. J Field Ornithol 53:235-239

U.S.G.S.-US Geological Survey, Patuxent Wildlife Research Center (1993-2007) North American Breeding Bird Survey. US Geological Survey, Patuxent Wildlife Research Center, Laurel, MD. http://www.pwrc.usgs.gov/bbs/results/

Wacker DW, Schlinger BA, Wingfield JC (2008) Combined effects of DHEA and fadrozole on aggression and neural VIP immunoreactivity in the non-breeding male song sparrow. Horm Behav 53:287-294

Webster JD (1975) The fox sparrow in Southwestern Yukon and adjacent areas. Condor 77:215-216

Weckstein JD, Kroodsma DE and Faucett RC (2002) Fox sparrow (Passerella iliaca). In: Poole A (ed) The birds of North America online, Cornell Laboratory of Ornithology, http://bna.birds. cornell.edu/bna/species/715
Wingfield JC (1984) Environmental and endocrine control of reproduction in the song sparrow, Melospiza melodia. II. Agonistic interactions as environmental information stimulating secretion of testosterone. Gen Comp Endocrinol 56:417-424

Wingfield JC (1985) Short-term changes in plasma levels of hormones during establishment and defense of a breeding territory in male song sparrows Melospiza melodia. Horm Behav 19:174-187

Wingfield JC, Farner DS (1975) The determination of five steroids in avian plasma by radioimmunoassay and competitive proteinbinding. Steroids 26:311-321

Wingfield JC, Farner DS (1978) The endocrinology of a natural breeding population of the white crowned sparrow Zonotrichia leucophrys pugetensis. Physiol Zool 51:188-205

Wingfield JC, Hahn TP (1994) Testosterone and territorial behaviour in sedentary and migratory sparrows. Anim Behav 47:77-89

Wingfield JC, Hunt KE (2002) Arctic spring: hormone-behaviour interactions in a severe environment. Comp Biochem Physiol B 132B:275-286

Wingfield JC, Wada M (1989) Male-male interactions increase both luteinizing hormone and testosterone in the song sparrow, Melospiza melodia: specificity, time course and possible neural pathways. J Comp Physiol A 166:189-194

Wingfield JC, Hegner RF, Dufty AMJ, Ball GF (1990) The challenge hypothesis theoretical implications for patterns of testosterone secretion mating systems and breeding strategies. Am Nat 136: 829-846

Wingfield JC, Lynn S, Soma KK (2001) Avoiding the 'costs' of testosterone: ecological bases of hormone-behaviour interactions. Brain Behav Evol 57:239-251

Wingfield JC, Moore IT, Goymann W, Wacker DW, Sperry TS (2006) Contexts and ethology of vertebrate aggression: implications for the evolution of hormone-behaviour interactions. In: Nelson RJ (ed) Contexts and ethology of vertebrate aggression: implications for the evolution of hormone-behaviour interactions. Oxford University Press, New York, pp 179-210

Wingfield JC, Meddle SL, Moore I, Busch S, Wacker D, Lynn S, Clark A, Vasquez RA, Addis E (2007) Endocrine responsiveness to social challenges in northern and southern hemisphere populations of Zonotrichia. J Ornithol 148:S435-S441

Zink RM (1994) The geography of mitochondrial DNA variation, population structure, hybridization, and species limits in the fox sparrow (Passerella iliaca). Evolution 48:96-111

Zink RM, McKitrick MC (1995) The debate over species concepts and its implications for ornithology. Auk 112:701-719

Zink RM, Weckstein JD (2003) Recent evolutionary history of the fox sparrows (genus: Passerella). Auk 120:522-527 